\title{
PENERAPAN PEMBELAJARAN TEMATIK TERPADU ERA DARING DI MADRASAH IBTIDAIYAH
}

\author{
Yuliana Susanti \\ STIT Palapa Nusantara Lombok NTB \\ yulianasusantimpd@gmail.com
}

\begin{abstract}
This study aims to describe the planning, implementation, assessment, barriers, efforts, and the impact of integrated thematic learning at MI Birrul Walidain NW Rensing and MI NW Bungtiang 2. The study used qualitative descriptive. Data collection techniques using observation, interviews, and document studies. The results of the study (1) planning, the teacher makes RPP according to the 2013 Curriculum component, (2) implementation, the teacher combines KD in subjects (thematics) through a scientific approach, (3) assessment, includes knowledge, attitudes, and skills, (4) barriers, time allocation for making lesson plans, learning variations, questioning activities, infrastructure and assessment facilities are still lacking, (5) efforts, teachers prepare lesson plans, learning variations, using media and the surrounding environment, (6) the impact of knowledge, skills and student attitudes is still quite good because students are not familiar with the online learning system.
\end{abstract}

Keywords: Thematic Learning, Online Era, Madrasah Ibtidaiyah

\begin{abstract}
Abstrak : Penelitian ini bertujuan untuk mendeskripsikan perencanaan, pelaksanaan, penilaian, hambatan, upaya, dan dampak pembelajaran tematik terpadu di MI Birrul Walidain NW Rensing dan MI NW Bungtiang 2. Penelitian menggunakan deskriptif kualitatif. Teknik pengumpulan data menggunakan observasi, wawancara, dan studi dokumen. Hasil penelitian (1) perencanaan, guru membuat RPP sesuai komponen Kurikulum 2013, (2) pelaksanaan, guru memadukan KD pada mata pelajaran (tematik) melalui pendekatan saintifik, (3) penilaian, mencakup pengetahuan, sikap, dan keterampilan, (4) hambatan, alokasi waktu membuat RPP, variasi belajar, kegiatan menanya, sarana prasarana dan penilaian masih kurang, (5) upaya, guru menyusun RPP, variasi belajar, menggunakan media dan lingkungan sekitar, (6) dampak pengetahuan keterampilan dan sikap siswa masih cukup baik, karena siswa belum terbiasa dengan sistem pembelajaran daring.
\end{abstract}

Kata Kunci : Pembelajaran Tematik, Era Daring, Madrasah Ibtidaiyah

AS-SABIQUN : Jurnal Pendidikan Islam Anak Usia Dini

Volume 3, Nomor 1, Maret 2021; 64-75

https://ejournal.stitpn.ac.id/index.php/assabiqun 


\section{PENDAHULUAN}

Pendidikan di Indonesia bertujuan mencerdaskan bangsa sehingga diperlukan suatu inovasi dalam mewujudkannya. Berbagai upaya dilakukan diantaranya perubahan kurikulum yang menitikberatkan pada peningkatan kompetensi yang dibutuhkan misalkan penerapan pendidikan karakter, pembelajaran aktif dalam proses pembelajaran dan berpusat pada siswa. Kurikulum 2013 adalah salah satu upaya untuk memperbaiki kurikulum sebelumnya. Diberlakukannya kurikulum 2013 diharapkan dapat menghasilkan lulusan yang berkompeten dan diharapkan dapat meningkatkan hasil belajar siswa dari segi kognitif, afektif, dan psikomotor. Kurikulum 2013 menekankan pada pembentukan karakter siswa ${ }^{1}$. Pembelajaran yang diterapkan dalam kurikulum 2013 adalah pembelajaran tematik terpadu.

Kegiatan pembelajaran berbasis tematik didasarkan pada sebuah tema yang di dalam tema tersebut terdiri dari beberapa mata pelajaran yang digabungkan menjadi sebuah tema. Pembelajaran tematik didefinisikan sebagai pembelajaran yang dirancang berdasarkan yang khusus tema ${ }^{2}$. Suatu pembelajaran tematik terpadu memungkinkan siswa baik secara individu ataupun kelompok untuk menggali serta menemukan konsep holistik, otentik, dan bermakna ${ }^{3}$. Pembelajaran tematik Sekolah Dasar/Madrasah Ibtidaiyah di Indonesia, berdasarkan kurikulum tematik terpadu 2013 merupakan integrasi antar disiplin, multidisiplin, dan transdisipliner ${ }^{4}$. Jadi, pembelajaran tematik di Sekolah Dasar/Madrasah Ibtidaiyah untuk mengintegrasikan dimensi sikap, pengetahuan, dan keterampilan menjadi satu kesatuan, menggabungkan kompetensi dari beberapa pelajaran dasar untuk dihubungkan satu sama lain sehingga setiap pelajaran masih memiliki kompetensi dasar sendiri dan menghubungkan berbagai mata pelajaran dengan lingkungan di sekitarnya.

\footnotetext{
${ }^{1}$ Lazim. 2014. Penerapan Pendekatan Saintifik dalam Pembelajaran Kurikulum 2013. Yogyakarta

${ }^{2}$ Narti, Y., Setyosari, P., Degeng, I. N. S., \& Dwiyogo, W. D. (2016). Thematic Learning Implementation in Elementary School (Phenomenology Studies in Pamotan SDN 01 and 01 Majangtengah Dampit Malang). International Journal of Science and Research, 5(11), 1849-1855. https://doi.org/10.21275/ART20163223

${ }^{3}$ Majid, A. (2014). Pembelajaran Tematik Terpadu. Bandung: PT Remaja Rosdakarya.

${ }^{4}$ Hidayati, W., Tarbiyah, F., State, T., \& Kalijaga, S. (2016). Implementation of Curriculum 201 In Primary School Sleman Yogyakarta, 6(2), 6-12. https://doi.org/10.9790/7388-0602020612
} 
Pada Saat ini dunia Pendidikan sedang dihadapkan dengan tantangan yang berat dan rumit, yaitu wabah virus corona 2019. Wabah ini telah melumpuhkan berbagai aspek dalam kehidupan, salah satunya adalah Pendidikan. Dalam hal ini, pemerintah, satuan Pendidikan, guru, siswa dan orang tua, sedang berusaha beradaptasi dengan perubahan drastis yang diakibatkan wabah yang mematikan ini.

Dampak adanya wabah virus corona 2019 juga dirasakan pada proses belajar dan pembelajaran. Proses pembelajaran biasanya dilaksanakan di sekolah secara tatap muka agar adanya interaksi yang terlihat yaitu diantaranya guru dengan peserta didik atau sebaliknya. Namun sekarang ini, pembelajaran yang biasanya dilaksanakan di sekolah secara tatap muka dialihkan dengan pembelajaran daring. Hal tersebut dilaksanakan karena telah dikeluarkan surat edaran dari Menteri Pendidikan dan Kebudayaan Republik Indonesia tentang hal pembelajaran secara daring dari rumah dalam rangka pencegahan penyebaran Corona Virus Disease (Covid-19) yaitu a) memberlakukan pembelajaran secara daring dari rumah bagi siswa dan mahasiswa; b) pegawai, guru dan dosen melakukan aktivitas bekerja, mengajar atau memberi documents dan sarana daring lainnya; c) pelaksanaan belajar dari rumah tidak mempengaruhi tingkat kehadiran (dipandang sama seperti bekerja dikantor, sekolah atau perguruan tinggi), tidak mengurangi kinerja dan tidak mempengaruhi tunjangan kinerja; dan d) apabila harus datang ke kantor, kampus, sekolah sebaiknya tidak menggunakan sarana kendaraan (umum) yang bersifat massal sehingga semua kegiatan proses belajar dan pembelajaran dilaksanakan secara daring dari rumah.

Proses belajar dan pembelajaran daring diterapkan seharusnya sesuai dengan ketentuan kurikulum 2013 yang menerapkan pendekatan saintifik dengan langkah pembelajaran 5M yaitu mengamati, menanya, mencoba, menalar dan mengkomunikasikan ${ }^{5}$. Langkah-langkah tersebut diharapkan dapat dimunculkan secara menyeluruh dalam proses pembelajaran karena dengan adanya langkah tersebut peserta didik dapat menunjukkan kinerja yang positif dan aktif dalam mengikuti pembelajaran

\footnotetext{
${ }^{5}$ Izzuddin, Ahmad. 2019. Efektivitas Pendekatan Saintifik Terhadap Kemampuan Berpikir Kritis Siswa dalam Pembelajaran IPA Kelas V MI NW Bagik Nyala. Jurnal Al-Muta aliyah : Jurnal Pendidikan Guru Madrasah Ibtidaiyah, 4(1), 141 - 165
} 
yang diberikan. Hal ini selaras dengan tujuan pendidikan yang digunakan pada kurikulum 2013 yaitu menciptakan pengajaran yang dapat berpusat pada peserta $\operatorname{didik}^{6}$

Hasil wawancara dengan guru kelas V MI Birrul Walidain NW Rensing dan guru kelas IV MI NW Bungtiang 2 bahwa saat pembelajaran tematik terpadu Kurikulum 2013, guru telah diberikan pemahaman tentang cara membuat RPP, penilaian autentik dan salah satu didalamnya tentang bagaimana menggunakan pendekatan saintifik dalam pelaksanaan pembelajaran tematik. Dalam Kurikulum 2013 ini guru juga harus melakukan penilaian autentik. Penilaian autentik merupakan proses pengumpulan informasi tentang perkembangan belajar siswa ${ }^{7}$. Penilaian ini dilakukan oleh guru dalam proses pembelajaran. Sesuai dengan hasil wawancara dengan guru kelas V MI Birrul Walidain NW Rensing dan guru kelas IV MI NW Bungtiang 2 merasa kesulitan untuk melakukan penilaian kepada siswa ditambah lagi dengan proses pembelajaran daring yang memiliki banyak sekali hambatan dan kesulitan. Hasil wawancara dengan kepala sekolah, guru kelas, dan observasi terhadap pelaksanaan pembelajaran tematik terpadu melalui daring, maka peneliti tertarik untuk mengkaji lebih jauh mengenai penerapan pembelajaran tematik terpadu era daring di MI Birrul Walidain NW Rensing dan MI NW Bungtiang 2 .

\section{METODE}

Penelitian penerapan pembelajaran tematik terpadu di madrasah Ibtidaiyah ini menggunakan pendekatan kualitatif. Metode penelitian kualitatif yaitu prosedur sistematis yang telah disepakati untuk mengungkap suatu gejala yang menjadi objek penelitian ${ }^{8}$. Metode penelitian kualitatif adalah metode penelitian yang mengkaji suatu objek tanpa adanya manipulasi dan bersumber pada metode ilmiah atau dari fenomena yang telah diamati'. Penelitian kualitatif ini lebih cenderung bersifat ilmiah dan tanpa adanya pengujian hipotesis.

${ }^{6}$ Pursitasari, I. D., Nuryanti, S., \& Rede, A. (2015). Promoting of Thematic-based Integrated Science Learning on the Junior High School, 6(20), 97-102.

${ }^{7}$ Sa'ud, U. S. (2013). Inovasi Pendidikan. Bandung: Alfabeta.

${ }^{8}$ Hanurawan. (2016). Metode Penelitian Kualitatif untuk Ilmu Psikologi. Jakarta: Rajawali Press.

${ }_{9}$ Prastowo, A. (2012). Metode Penelitian Kualitatif dalam Perspektif Rancangan Penelitian. Yogyakarta: Ar-Ruzz Media. 
Rancangan penelitian ini adalah studi kasus. Penelitian studi kasus merupakan penyelidikan yang mendalam terhadap seseorang secara intensif ${ }^{10}$. Studi kasus pada dasarnya kajian berisi aspek tentang masalah, konteks dan isu ${ }^{11}$. Dalam penelitian dengan pendekatan studi kasus ini memberikan penjelasan secara detail dan lengkap terhadap suatu fenomena sosial tentang penerapan pembelajaran tematik terpadu era daring di MI Birrul Walidain NW Rensing dan MI NW Bungtiang 2 .

Penelitian mengenai penerapan pembelajaran tematik terpadu era daring di MI Birrul Walidain NW Rensing dan MI NW Bungtiang 2 dengan subjek penelitian dalam penelitian ini, yaitu guru kelas V MI Birrul Walidain NW Rensing dan guru kelas IV MI NW Bungtiang 2. Data yang digunakan sebagai acuan untuk mendeskripsikan penerapan pembelajaran tematik terpadu era daring di MI Birrul Walidain NW Rensing dan MI NW Bungtiang 2 diperoleh dari hasil observasi, wawancara dan studi dokumen. Teknik analisis data yang dilakukan dalam penelitian ini, yaitu data reduction, data display, dan conclusion drawing/verification.

\section{HASIL PENELITIAN DAN PEMBAHASAN}

\section{Perencanaan Pembelajaran Tematik Terpadu}

Perencanaan pembelajaran merupakan suatu proses penentu rencana dalam kegiatan pembelajaran yang akan dilakukan secara terpadu dan sistematis. Perencanaan yang dibuat dituangkan ke dalam Rencana Pelaksanaan Pembelajaran (RPP). Dalam hal ini guru berkewajiban menyusun RPP secara lengkap dan sistematis. Berdasarkan wawancara dan studi dokumen dengan guru kelas V MI Birrul Walidain NW Rensing bahwa RPP dibuat secara mandiri oleh guru. Dalam membuat RPP, guru kelas V MI Birrul Walidain NW Rensing dilakukan per tema. RPP yang dibuat oleh guru kelas V MI Birrul Walidain NW Rensing merupakan RPP yang sudah mencerminkan Kurikulum 2013 yang memuat komponen identitas RPP yaitu kompetensi inti, kompetensi dasar, indikator, tujuan, materi, pendekatan, metode, media, sumber belajar, langkah-langkah kegiatan pembelajaran dan penilaian dalam suatu proses pembelajaran serta di dalam

${ }^{10}$ Furchan, A. (2011). Pengantar Penelitian dalam Pendidikan. Yogyakarta: Pustaka Pelajar Offset.

11 Moedzakir. (2010). Desain dan Model Penelitian Kualitatif. Malang: Fakultas Ilmu Pendidikan Universitas Negeri Malang. 
RPP tersebut sudah memuat pendekatan saintifik. Pendekatan saintifik digunakan oleh guru karena pada kurikulum 2013 sudah jelas bahwa pembelajarannya merupakan pembelajaran tematik terpadu dengan menggunakan pendekatan saintifik.

Selain itu, berdasarkan wawancara dan studi dokumen yang dilakukan peneliti dengan guru kelas IV MI NW Bungtiang 2 bahwa dalam membuat RPP, guru kelas IV MI NW Bungtiang 2 dilakukan setiap hari sebelum pembelajaran daring dilakukan, sehingga dapat dikatakan RPP dibuat per-pertemuan. Guru membuat RPP dengan pendekatan saintifik berpedoman pada silabus, buku guru dan buku siswa. Dalam membuat RPP untuk langkah-langkah kegiatan pembelajaran guru sudah mencerminkan sesuai dengan yang ada pada pendekatan saintifik, meliputi kegiatan mengamati, menanya, mengumpulkan informasi, menalar, dan mengomunikasikan, walaupun di dalam RPP guru tidak menuliskan secara rinci langkah pembelajaran mana yang termasuk kegiatan mengamati, menanya, mengumpulkan informasi, menalar, dan mengomunikasikan. Berdasarkan perencanaan pembelajaran berupa RPP yang telah dibuat oleh guru kelas V MI Birrul Walidain NW Rensing dan guru kelas IV MI NW Bungtiang 2 sudah mencakup semua komponen sesuai dengan pembelajaran tematik terpadu Kurikulum 2013.

\section{Pelaksanaan Pembelajaran Tematik Terpadu}

Pembelajaran tematik terpadu telah dilaksanakan oleh guru dengan menggabungkan Kompetensi Dasar dari mata pelajaran dan guru menggunakan buku guru sebagai acuan dalam pembelajaran. Pelaksanaan pembelajaran tematik terpadu didukung dengan pendekatan saintifik dalam proses pembelajarannya. Hasil wawancara dengan guru kelas V MI Birrul Walidain NW Rensing dan kelas IV MI NW Bungtiang 2 bahwa dalam pembelajaran tematik terpadu sesuai dengan RPP yang dibuat oleh guru. Penerapan pembelajaran sudah menggunakan pendekatan saintifik dalam pembelajaran tematik terpadu. Akan tetapi terjadi sedikit masalah karena dilakukan dengan metode daring. Materi yang bisa dilakukan dengan sistem daring sepenuhnya dilakukan melalui media Whatsapp dengan tetap memperhatikan urutan kegiatan yang telah disusun di RPP. Apabila ada beberapa materi yang tidak memungkinkan untuk dilakukan secara daring, kedua guru kelas tersebut berinisiatif mengumpulkan beberapa orang siswa di sekolah untuk diberikan penjelasan kemudian diberikan tugas yang dikumpulkan lewat 
media yang disediakan. Pelaksanaan pembelajaran tematik terpadu secara daring ini memiliki tingkat kesulitan yang cukup tinggi disebabkan sarana dan prasarana yang masih sangat terbatas.

Pelaksanaan pembelajaran tematik terpadu era daring ini tidak menitikberatkan pada susunan RPP. Terkadang pelaksanaannya disesuaikan dengan kondisi saat pembelajaran berlangsung. Pembelajaran tematik terpadu era daring diawali dengan kegiatan pendahuluan. Pada kegiatan ini terkadang guru melakukannya dengan mengumpulkan siswa dengan sistem shif (giliran). Kegiatan pendahuluan yang pertama yaitu pra-kegiatan, guru memberi salam dan siswa berdoa sebelum memulai kegiatan, yang kedua apersepsi yaitu guru memberikan apersepsi kepada siswa berupa motivasi.

Kegiatan pembelajaran tematik terpadu selanjutnya yaitu kegiatan inti. Pada kegiatan inti ini guru menggunakan pendekatan saintifik. Akan tetapi dengan adanya sitem daring, guru merasa kesulitan untuk melakukan langkah-langkah pendekatan tersebut. Guru harus memiliki inovasi dan kreatifitas untuk menyampaikan materi sesuai Langkahlangkah pendekatan saintifik. Kegiatan penutup. Pada kegiatan ini guru memberikan evaluasi tertulis serta memberikan tindak lanjut berupa tugas rumah dan menginformasikan kepada siswa untuk pembelajaran berikutnya. Penerapan pembelajaran tematik terpadu dengan pendekatan saintifik di kelas V MI Birrul Walidain NW Rensing dan kelas IV MI NW Bungtiang 2 telah terlihat walaupun pembelajarannya dilakukan secara daring.

\section{Penilaian Pembelajaran Tematik Terpadu}

Kurikulum 2013 menekankan adanya penilaian pengetahuan, sikap, dan keterampilan sehingga guru harus melakukan ketiga penilaian tersebut. Hasil wawancara dengan guru kelas V MI Birrul Walidain NW Rensing dan kelas IV MI NW Bungtiang 2 bahwa penilaian yang dilakukan sudah mencakup pengetahuan, sikap dan keterampilan. Penilaian sikap dinilai menggunakan lembar observasi sesuai dengan yang ada di RPP yang dikombinasikan dengan keadaan saat pembelajaran daring berlangsung. Dokumen yang dimiliki oleh guru kelas V MI Birrul Walidain NW Rensing dan guru kelas IV MI NW Bungtiang 2 telah menunjukan bahwa guru melakukan penilaian terhadap sikap, 
pengetahuan dan keterampilan. Dokumen menunjukkan bahwa guru telah melaksanakan penilaian pengetahuan, sikap, dan keterampilan pada setiap muatan atau pelajaran. Dari penilaian yang dilakukan guru selanjutnya hasil belajar siswa kemudian dimasukan ke dalam daftar nilai kelas yang nantinya akan dimasukkan ke dalam rapor.

Berdasarkan studi dokumen tentang penilaian proses hasil belajar yang dilakukan oleh guru kelas V MI Birrul Walidain NW Rensing dan guru kelas IV MI NW Bungtiang 2 yaitu guru memiliki daftar nilai yang digunakan untuk menilai setiap kemampuan siswanya baik pengetahuan, sikap spiritual, sikap sosial, dan keterampilan yang selanjutnya akan dimasukkan guru ke dalam rapor yang ditulis angka dan deskripsi. Berdasarkan pernyataan hasil wawancara, observasi dan dokumen terkait dengan penilaian belajar siswa dapat disimpulkan bahwa guru telah melaksanakan penilaian pengetahuan, sikap, dan keterampilan. Adapun nilai yang tertera di raport tidak menunjukkan ketercapaian kurikulum secara keseluruhan, disebabkan kondisi wabah pandemi covid-19. Guru hanya membatasi keterserapan kurikulum berdasarkan tema yang telah tuntas disampaikan dan diujikan.

\section{Hambatan dan Upaya Mengatasi Penerapan Pembelajaran Tematik Terpadu}

Pembelajaran tematik terpadu dalam proses penerapannya di kelas terdapat beberapa hambatan yang dialami oleh guru, di antaranya (1) hambatan dalam perencanaan pembelajaran tematik terpadu. Hasil wawancara dengan guru kelas V MI Birrul Walidain NW Rensing dan guru kelas IV MI NW Bungtiang 2 bahwa guru mengalami hambatan dalam pembuatan RPP yang banyak memakan waktu lama karena guru harus memilih Kompetensi Inti (KI) dan Kompetensi Dasar (KD) sesuai dengan muatan pelajaran, (2) hambatan dalam pelaksanaan pembelajaran tematik terpadu. Hasil wawancara dan observasi dengan guru kelas V MI Birrul Walidain NW Rensing dan guru kelas IV MI NW Bungtiang 2 yaitu guru yang mengajar hanya berpatokan pada buku guru dan buku siswa serta kondisi sarana dan prasarana saat pembelajaran daring berlangsung (3) hambatan dalam penilaian proses dan hasil belajar. Berdasarkan hasil wawancara, dokumen dan observasi yaitu kurang maksimalnya proses pembelajaran disebabkan kondisi dan aturan yang selalu berubah setiap saat. Hal ini terlihat dari beberapa edaran yang cenderung membuat guru merasa kebingungan saat berinteraksi dengan siswa, khusunya pada saat pembelajaran daring. 
Hambatan-hambatan yang dialami tersebut, guru memiliki beberapa upaya untuk mengatasinya. Hasil wawancara dengan guru kelas V MI Birrul Walidain NW Rensing dan guru kelas IV MI NW Bungtiang 2, upaya guru dalam mengatasi hambatan yang terjadi yaitu (1) untuk mengatasi hambatan waktu yang lama dalam pembuatan RPP yaitu guru kelas V MI Birrul Walidain NW Rensing menggunakan RPP pada tahun sebelumnya. Karena materi yang ada di kelas $\mathrm{V}$ tahun ini dengan tahun lalu sama dan tidak ada revisi dan buku tematik siswa juga masih sama tidak ada revisi, (2) guru yang mengajar hanya berpatokan pada buku guru dan buku siswa tanpa mengembangkannya sehingga kurang bervariasi, akan tetapi keadaan ini cukup membantu karena siswa memiliki aktivitas di rumah yaitu membaca dan memahami materi yang diberikan, (3) sarana prasarana seperti jaringan wifi maupun paket data yang kurang maksimal karena hanya mengandalkan dari orang tua saja, pihak madrasah belum mampu memberi subsidi kepada siswa, (4) penilaian yang rumit, guru harus menilai per muatan pelajaran, dan membuat deskripsi pada masing-masing muatan pelajaran dalam penulisan rapor.

\section{Dampak Pembelajaran Tematik Terpadu}

Penerapan pembelajaran tematik terpadu yang sudah dilakukan oleh guru khususnya guru kelas V MI Birrul Walidain NW Rensing memberikan dampak kepada siswa. Berdasarkan hasil wawancara dan observasi, dampak pembelajaran tematik terpadu tersebut di antaranya (1) dalam proses pembelajaran siswa lebih aktif karena siswa dapat belajar dengan metode yang telah ditentukan dan sarananya yang disiapkan seperti buku siswa. Selaian itu siswa juga lebih tanggung jawab terhadap tugas yang diberikan oleh guru, (2) kegiatan pembelajaran untuk keterampilan siswa cukup bagus, akan lebih bagus lagi jika pembelajaran dilakukan secara tatap muka, akan tetapi karena kondisi yang tidak memungkinkan maka pembelajaran daring yang sudah dilakukan cukup efektif karena semua tugas yang diberikan dikerjakan dengan penuh tanggung jawab dan dikumpulkan sesuai waktu yang ditentukan, dan (3) sikap siswa belum dapat dilihat dengan maksimal, akan tetapi dengan melihat tanggung jawab siswa terhadap tugas yang diberikan. Selain itu saat sesekali dilakukan pembelajaran tatap muka, siswa tertib saat melakukan berdoa di awal maupun akhir pembelajaran. 
Selain itu, penerapan pembelajaran tematik terpadu juga dilakukan oleh guru kelas IV MI NW Bungtiang 2 dan juga memberikan dampak kepada siswa. Berdasarkan hasil wawancara dan observasi dampak pembelajaran tematik terpadu tersebut di antaranya (1) untuk pengetahuan siswa sedikit lebih di bawah, jika dibandingkan dengan pembelajaran pada kurikulum sebelumnya. Hal ini terjadi karena materi pembelajaran dalam Kurikulum 2013 memang relatif lebih mudah dan kesannya kurang mendalam. Namun dalam proses belajar siswa mengalami sedikit kesulitan karena harus melakukannya dengan daring, (2) keterampilan siswa secara umum lebih berkembang karena kegiatan pembelajaran daring ini di samping membuat siswa banyak dikenalkan hal baru juga diberikan banyak penugasan yang bisa meningkatkan rasa tanggung jawab mereka.

Berdasarkan paparan data di atas dapat disimpulkan bahwa penerapan pembelajaran tematik terpadu memberikan dampak kepada siswa yaitu pengetahuan keterampilan dan sikap yang cukup baik. Proses pembelajaran yang dilakukan secara daring berpengaruh terhadap pengetahuan dan hasil belajar siswa. Hal ini disebabkan karena berbagai faktor antara lain (1) siswa belum terbiasa dengan penerapan pembelajaran daring yang merupakan hal baru bagi merekia, (2) adanya edaran yang mengatur sistem pembelajaran daring, belum disertai dengan juknis yang jelas, sehingga guru maupun siswa masih berusaha memahami sistem pembelajaran yang baru ini, (3) sarana dan prasarana terkait dengan pembelajaran daring ini seperti wifi dan paket data masih sangat terbatas.

\section{KESIMPULAN}

Berdasarkan hasil penelitian dan pembahasan dapat diperoleh kesimpulan bahwa penerapan pembelajaran tematik terpadu di kelas V MI Birrul Walidain NW Rensing dan kelas IV MI NW Bungtiang 2 telah terlaksana dengan baik. Berikut uraian kesimpulan sesuai dengan fokus penelitian.

Pertama, perencanaan pembelajaran yaitu penyusunan RPP sudah mencakup semua komponen, meliputi identitas RPP kompetensi inti, kompetensi dasar, indikator, tujuan pembelajaran, materi pembelajaran, pendekatan pembelajaran, metode 
pembelajaran, media pembelajaran, sumber belajar, langkah-langkah kegiatan pembelajaran, dan penilaian. RPP yang disusun sudah mencerminkan Kurikulum 2013 yaitu menggunakan pendekatan saintifik pada pembelajaran tematik terpadu dan RPP disusun sesuai dengan kebutuhan baik per-pertemuan, per subtema atau per tema.

Kedua, penilaian proses dan hasil belajar yaitu guru menilai siswa dari aspek (a) pengetahuan, menilai apa yang sudah dikerjakan siswa dalam buku siswa, (b) sikap spiritual dan sosial, menilai dengan lembar observasi; (c) keterampilan, menilai dengan lembar observasi dan kinerja. Dari ketiga aspek penilaian tersebut yang selanjutnya hasil laporan penilaian dicantumkan dalam rapor hasil belajar yang kemudian disampaikan oleh wali murid siswa.

Ketiga, hambatan yang dialami guru dalam penerapan pembelajaran tematik terpadu, meliputi penyusunan RPP yang membutuhkan waktu lama karena pada Kurikulum 2013 ini menggunakan tematik.

Ketiga, upaya yang dilakukan guru untuk mengatasi hambatan yang terjadi saat proses pembelajaran yaitu penyusunan RPP dilakukan per tema dengan melihat dokumen guru pada tahun sebelumnya serta berdiskusi dengan guru yang lainnya.

Keempat, proses pembelajaran yang dilakukan secara daring sangat berpengaruh terhadap hasil belajar, keterampilan dan sikap siswa. Hal ini disebabkan berbagai fkctor terutama sarana dan prasarana yang masih sangat terbatas

Berdasarkan kesimpulan, saran yang diberikan adalah guru hendaknya lebih meningkatkan dan mengembangkan perencanaan, pelaksanaan dan penilaian pembelajaran dengan menerapkan pendekatan saintifik pada pembelajaran tematik terpadu sesuai ketentuan yang berlaku, sehingga pembelajaran akan lebih efektif. Guru juga harus sesegera mungkin beradaptasi dengan sistem pembelajaran daring. Hal ini akan menjadi tantangan tersendiri bagi guru untuk membuat inovasi dan kratifitas dalam menyusun perencanaan pembelajaran khususnya berkaitan dengan pembelajaran daring. 


\section{DAFTAR PUSTAKA}

Furchan, A. (2011). Pengantar Penelitian dalam Pendidikan. Yogyakarta: Pustaka Pelajar Offset.

Hanurawan. (2016). Metode Penelitian Kualitatif untuk Ilmu Psikologi. Jakarta: Rajawali Press.

Hidayati, W., Tarbiyah, F., State, T., \& Kalijaga, S. (2016). Implementation of Curriculum 201 In Primary School Sleman Yogyakarta, 6(2), 6-12. https://doi.org/10.9790/7388-0602020612

Izzuddin, Ahmad. 2019. Efektivitas Pendekatan Saintifik Terhadap Kemampuan Berpikir Kritis Siswa dalam Pembelajaran IPA Kelas V MI NW Bagik Nyala. Jurnal Al-Muta aliyah : Jurnal Pendidikan Guru Madrasah Ibtidaiyah, 4(1), 141 $-165$

Lazim. 2014. Penerapan Pendekatan Saintifik dalam Pembelajaran Kurikulum 2013. Yogyakarta

Majid, A. (2014). Pembelajaran Tematik Terpadu. Bandung: PT Remaja Rosdakarya.

Moedzakir. (2010). Desain dan Model Penelitian Kualitatif. Malang: Fakultas Ilmu Pendidikan Universitas Negeri Malang.

Narti, Y., Setyosari, P., Degeng, I. N. S., \& Dwiyogo, W. D. (2016). Thematic Learning Implementation in Elementary School (Phenomenology Studies in Pamotan SDN 01 and 01 Majangtengah Dampit Malang). International Journal of Science and Research, 5(11), 1849-1855. https://doi.org/10.21275/ART20163223

Prastowo, A. (2012). Metode Penelitian Kualitatif dalam Perspektif Rancangan Penelitian. Yogyakarta: Ar-Ruzz Media.

Pursitasari, I. D., Nuryanti, S., \& Rede, A. (2015). Promoting of Thematic-based Integrated Science Learning on the Junior High School, 6(20), 97-102.

Sa’ud, U. S. (2013). Inovasi Pendidikan. Bandung: Alfabeta. 